\title{
ANALISIS STAKEHOLDERS DALAM PERSPEKTIF GOVERNANCE: Upaya Pencegahan Penyebaran Berita Bohong (Hoax) di Jawa Tengah
}

\author{
Kismartini'1), Ihram Kustarto2), Budi Puspo Priyadi3) \\ ${ }^{1)}$ Magister IImu Administrasi, FISIP, Universitas DIponegoro \\ kis_martini@yahoo.co.id \\ ${ }^{2)}$ Magister IImu Administrasi, FISIP, Universitas DIponegoro \\ ihram8205@gmail.com
}

\begin{abstract}
Abstrak
Kemajuan media internet saat ini sering dimanfaatkan sebagai sarana utama mendukung propaganda untuk tujuan tertentu. Propaganda yang penyebarannya melalui media online yaitu dapat berupa berita bohong (hoax). Beberapa tahun terakhir, di Jawa Tengah telah muncul berbagai berita hoax penculikan anak. Daerah penyebaran berita hoax penculikan anak yaitu Kota Semarang, Kota dan Kabupaten Tegal, Kabupaten Brebes, Kabupaten Cilacap, Kecamatan Weru Sukoharjo, Kabupaten Banyumas, Kota dan Kabupaten Pekalongan, Kabupaten Batang dan Kabupaten Demak. Penyebaran berita bohong tentang penculikan anak tersebut sangat cepat karena beredar melalui media sosial. Seiring meningkatnya pengetahuan dan pengaruh globalisasi maka hubungan sinergis dan konstruktif diantara stakeholders yaitu negara, swasta dan masyarakat dinilai sangat penting. Tujuan dari penelitian ini yaitu untuk menganalisis peran stakeholders di Provinsi Jawa Tengah dalam pencegahan penyebaran berita bohong (hoax) ditinjau dari perspektif governance beserta kendala pelibatan stakeholders. Penelitian ini menggunakan pendekatan kualitatif dengan metode deskriptif. Teknik analisis data yang digunakan yaitu analisis data interaktif. Berdasarkan hasil penelitian dan analisis data dapat diketahui bahwa Negara memiliki komitmen yang baik, diawali dengan penyusunan dan pengesahan Undang-undang Nomor 11 Tahun 2008 tentang Informasi dan Transaksi Elektronik. Dalam penyusunan dan implementasinya, pemerintah bekerjasama dengan swasta dan masyarakat untuk memerangi berita bohong. Kendala peran stakeholders dalam pencegahan penyebaran berita bohong yaitu masih banyak masyarakat yang tidak mengetahui Undang-undang ITE, situs yang mengandung berita bohong, pornografi dan SARA sangat banyak dan tidak semua dapat dijangkau oleh pemerintah, serta terdapat banyak penolakan terhadap revisi undang-undang ITE karena pemerintah memiliki akses dan kebebasan dalam melakukan pemblokiran terhadap situs/ akun milik masyarakat.
\end{abstract}

Kata Kunci: berita bohong (hoax), good governance, stakeholders

\begin{abstract}
These days internet is primarily needs of technology advances which used for propaganda. One of essential object of propaganda is widespread of misleading information (hoax). In addition, Central Java had several issues such as children trafficking. Semarang City, Tegal District, Brebes District, Cilacap District, Weru Sub-District Sukoharjo, Banyumas District, Pekalongan District, Batang District, Demak District was exposed by malicious deception (hoax). The widespread misleading information about children smuggling through social media has significant effect. It could be brought an domino issues, hence it needs a good communication among state, private, and society. The aim of this research is for analyze the role of stakeholders in Central Java addressing the preventive toward of hoax in terms of governance perspective also stakeholder obstacles involved. Descriptive qualitative is used for this study, analytical data technique is used to support also interactive data. According the latest research and data analyze Indonesia has high commitment. Meanwhile, Law number 11 Year of 2008 about Information and Electronic Transaction mentioned The Government was built cooperation between private and society to prevent and fight of misleading information. In other hand, there are a lot sites contain of hoax, pornography, or containing ethnicity, religion, race, and inter-group relations issues cannot cover by governance, while many rejection revised of law, it could be due to the government has access, and free to block the harmful site.
\end{abstract}

Keyword: misleading information (hoax), good governance, stakeholders

*doi: 10.33510/skiki.2019.21-28 


\section{PENDAHULUAN}

Internet merupakan salah satu kemajuan teknologi yang memudahkan penggunannya untuk bertukar informasi tanpa harus bertatap muka dengan orang lain (Hendriana, 2017:1). Selain itu adanya internet juga mendorong munculnya sistem elektronik berbasis jaringan. Badan Pusat Statistik (BPS) bekerjasama dengan Asosiasi Penyelenggara Jasa Internet Indonesia (APJII) mencatat angka pertumbuhan pengguna internet di Indonesia hingga akhir tahun 2016 sudah mencapai 132,7 juta orang. Tren yang ada tidak hanya berkaitan dengan pengadopsian infrastruktur telekomunikasi terbaru tetapi juga berkaitan dengan gaya pemakaian perangkatnya di masyarakat. Kemajuan media internet tersebut sering dimanfaatkan sebagai sarana utama guna mendukung propaganda untuk tujuan tertentu. Informasi yang berisi provokasi, agitasi, serta propaganda (upaya yang disengaja dan sistematis untuk membentuk persepsi, manipulasi alam pikiran dan pengaruh langsung perilaku seseorang agar memberikan respon sesuai yang dikehendaki pelaku propaganda) kemudian akan disebarkan secara terus menerus melalui media online karena akan semakin terasa dampaknya.

Hasil survey Asosiasi Penyelenggara Jasa Internet Indonesia (APJII) tahun 2016 menunjukkan bahwa $97,4 \%$ adalah pengakses media sosial dengan tingkat frekwensi yang paling sering dikunjungi adalah facebook $54 \%$, instagram $15 \%$, youtube $11 \%$, google+ $6 \%$, tweeter $5,5 \%$ dan Linkedln $0,6 \%$. Survei dari APJII ini memperlihatkan besarnya akses masyarakat Indonesia dalam menggunakan media sosial. Penggunaan media sosial berkontribusi besar dalam penyebaran berita bohong, hal ini dapat dilihat dari survey yang dilakukan Masyarakat Telekomunikasi (Mastel). Berdasarkan survey Mastel tahun 2016 juga dapat diketahui bahwa ditemukan kecenderungan untuk meneruskan berita bohong dengan alasan: (1) Didapat dari orang yang dipercaya sebesar $47,10 \%$, (2) Mengira bermanfaat sebesar $31,90 \%$, (3) Mengira benar sebesar $18 \%$ dan (4) Ingin jadi yang pertama tahu sebesar $3 \%$.

Berbagai upaya telah dilakukan pemerintah dalam menangkal informasi hoax yang beredar ke masyarakat, baik melalui Kementrian Komunikasi dan Informatika (Kominfo) maupun Kepolisian Republik Indonesia (Polri). Pemerintah juga telah mengesahkan undang-undang yang mengatur sanksi bagi pelaku penyebar berita bohong. Mengenai sanksi dari penyebaran berita bohong terdapat pada UndangUndang Nomor 19 Tahun 2016 tentang Perubahan atas Undang-Undang Nomor 11 Tahun 2008 tentang Informasi dan Transaksi Elektonik pasal $45 \mathrm{~A}$ yang berbunyi :

(1) Setiap Orang yang dengan sengaja dan tanpa hak menyebarkan berita bohong dan menyesatkan yang mengakibatkan kerugian konsumen dalam Transaksi Elektronik sebagaimana dimaksud dalam Pasal 28 ayat (1) dipidana dengan pidana penjara paling lama 6 (enam) tahun dan/atau denda paling banyak Rp1.000.000.000,00 (satu miliar rupiah).

(2) Setiap Orang yang dengan sengaja dan tanpa hak menyebarkan informasi yang ditujukan untuk menimbulkan rasa kebencian atau permusuhan individu dan/atau kelompok masyarakat tertentu berdasarkan atas suku, agama, ras, dan antargolongan (SARA) sebagaimana dimaksud dalam Pasal 28 ayat (2) dipidana dengan pidana penjara paling lama 6 (enam) tahun dan/atau denda paling banyak Rp1.000.000.000,00 (satu miliar rupiah).

Telah muncul di Jawa Tengah berbagai berita hoax penculikan anak yang sempat merebak di berbagai daerah dan membuat keresahan para orang tua (dilansir dari tribatanewspoldajateng.com tanggal 5 Maret 2017diakses pada tanggal 25 April 2017). Daerah penyebaran berita hoax penculikan anak yaitu Kota Semarang, Kota dan Kabupaten Tegal, Kabupaten Brebes, Kabupaten Cilacap, Kecamatan Weru Sukoharjo, Kabupaten Banyumas, Kota dan Kabupaten Pekalongan, Kabupaten Batang dan Kabupaten Demak. Penyebaran berita bohong tentang penculikan anak tersebut sangat cepat karena beredar melalui media sosial. Sedangkan akhir-akhir ini hoax kembali marak melalui momentum Pilpres 2019. Salah satu kasus yang menonjol belakangan ini adalah hoax kontainer berisi surat suara pilpres yang telah dicoblos untuk pasangan capres tertentu. 
Permasalahan hoax terkait dengan peran dari banyak pihak, diantaranya adalah masyarakat, pemerintah maupun dunia usaha. Masyarakat membuat hoax bisa jadi karena ketidakpuasan terhadap kebijakan pemerintah. Pemerintah juga bisa melakukan hoax mungkin ada keinginan mempertahankan kekuasaannya. Demikian juga dunia usaha bisa melakukan hoax untuk menjaga keberlanjutan usahanya.

Hoax adalah permasalahan yang berkembang ditengah-tengah masyarakat karena adanya kepentingan yang dimiliki oleh stakekolders, sehingga permasalahan ini menjadi kompleks. Kompleksnya permasalahan publik terkait dengan berbagai kepentingan memerlukan suatu analisis stakeholders, yang bertujuan untuk memahami kepentingan stakeholders dan bagaimana melibatkan nya dalam menangani permasalahan tersebut (Kismartini, 2004).

Untuk pencegahan hoax, tentu memerlukan dukungan dari berbagai stakeholders baik dari pihak negara, swasta, dan masyarakat. Peran negara melalui Dinas Kominfo sebagai instansi pemerintah yang berwenang dalam teknologi informasi, peran Kepolisian Daerah untuk tingkat Provinsi, Polres dan Polsek untuk tingkat Kabupaten/Kota sebagai instansi yang menjaga ketentraman dan ketertiban daerahserta penegakan hukum. Peran swastaseperti pengusaha layanan jaringan dan internet sebagai penyedia sarana teknologi informasi. Peran masyarakat seperti Lembaga Swadaya Masyarakat, serta komunitas masyarakat sebagai penyaring dan pemutus penyebaran berita bohong.

Berdasarkan permasalahan dalam latar belakang di atas, maka dapat diidentifikasikan beberapa masalah sebagai berikut:

1. Tingginya angka penetrasi pengguna internet sarat dengan muatan penyebaran berita hoax.

2. Tingginya persentase informasi yang bersifat hoax.

3. Merebaknya kasus berita hoax dengan latar belakang penculikan anak di Jawa Tengah.

\section{TINJAUAN PUSTAKA}

Pressman dan Widavsky (dalam Winarno, 2002:17) mendefinisikan kebijakan publik sebagai hipotesis yang mengandung kondisikondisi awal dan akibat-akibat yang bisa diramalkan. Kebijakan publik itu harus dibedakan dengan bentuk-bentuk kebijakan yang lain misalnya kebijakan swasta. Hal ini dipengaruhi oleh keterlibatan faktor-faktor bukan pemerintah. Robert Eyestone (dalam Agustino, 2008: 6), kebijakan publik sebagai "hubungan antara unit pemerintah dengan lingkungannya". Woll (dalam Tangkilisan, 2003: 2) menyebutkan bahwa kebijakan publik ialah sejumlah aktivitas pemerintah untuk memecahkan masalah di masyarakat, baik secara langsung maupun melalui berbagai lembaga yang mempengaruhi kehidupan masyarakat.

\section{Stakeholders}

Freeman (dalam Solihin, 2011:3) menjelaskan stakeholders sebagai individuindividu dan kelompok-kelompok yang dipengaruhi untuk tercapainya tujuan-tujuan organisasi dan pada gilirannya dapat mempengaruhi tujuan-tujuan tersebut. Definisi senada disampaikan oleh Kadiwaraka (2014: 47), Stakeholders adalah semua pihak baik secara individu maupun kelompok yang dapat dipengaruhi dan/atau memengaruhi pengambilan keputusan serta pencapaian tujuan suatu kegiatan

Brown et al. (dalam Kismartini, 2005:1113), analisis stakeholders adalah system pengumpulan informasi dari individu atau sekelompok orang yang berpengaruh di dalam memutuskan, mengelompokkan informasi dan menilai kemungkinan konflik yang terjadi antara kelompok-kelompok berkepentingan dengan areal dimana akan dilakukan trade-off.

\section{Good Governance}

G. Shabbir Cheema (dalam Keban, 2014: 38), governanceyaitu suatu nilai, kebijakan dan kelembagaan dimana urusan-uruasan ekonomi, sosial dan politik dikelola melalui interaksi antara masyarakat, pemerintah dan swasta. Dwiyanto (2008: 36) mengemukakan bahwa governance merupakan unsur yang terlibat dalam praktik good governance yang 
meliputi pemerintah sebagai representasi dari negara, pelaku pasar dan dunia usaha serta masyarakat sipil.

\section{Peran Stakeholders dari Perspektif Governance}

Soekanto (2002: 243), peran merupakan aspek dinamis kedudukan (status), apabila seseorang melaksanakan hak dan kewajibannya sesuai dengan kedudukannya, maka ia menjalankan suatu peranan.

Dalam proses demokratisasi, good governance sering mengilhalmi para aktivis pemerintah untuk mewujudkan pemerintahan yang memberikan ruang partisipasi yang luas bagi aktor dan lembaga di luar pemerintah sehingga ada pembagian peran dan kekuasaan yang seimbang antara negara, masyarakat sipil dan pelaku swasta. Adanya pembagian peran yang seimbang dan saling melengkapi antar ketiga unsur tersebut bukan hanya memungkinkan adanya check and balance tetapi juga menghasilkan sinergi yang baik antar ketiganya dalam mewujudkan kesejahteraan bersama (Dwiyanto, 2008:18)

Pada pencegahan penyebaran berita bohong (hoax) di Provinsi Jawa Tengah dari perspektif governance, instansi pemerintah daerah merupakan perpanjang tangan negara secara nasional yang menjadi aktor utama dari aktor lainnya. Masyarakat Provinsi Jawa Tengah sebagai perwujudan society dan pelaku ekonomi sebagai perwujudan private, yang dapat dipetakan sebagai berikut:

Tabel 1. Peta Governance Di Level Daerah

\begin{tabular}{|c|c|c|c|}
\hline $\begin{array}{l}\text { Elemen } \\
\text { Governance }\end{array}$ & Aktor & Arena & $\begin{array}{l}\text { Isu } \\
\text { Relasional }\end{array}$ \\
\hline Negara (State) & $\begin{array}{l}\text { Local State: } \\
\text { Gubernur, DPRD, } \\
\text { Instansi terkait }\end{array}$ & $\begin{array}{l}\text { Regulasi, kontrol } \\
\text { pada masyarakat, } \\
\text { pengelolaan } \\
\text { kebijakan, } \\
\text { keuangan, } \\
\text { pelayanan. }\end{array}$ & $\begin{array}{l}\text { Kepastian } \\
\text { Penegakan } \\
\text { Hukum, } \\
\text { Akuntabilitas, } \\
\text { transparansi } \\
\text { dan } \\
\text { responsivitas. }\end{array}$ \\
\hline $\begin{array}{l}\text { Masyarakat Sipil } \\
\text { (Society) }\end{array}$ & $\begin{array}{l}\text { Institusi Sosial, } \\
\text { organisasi LSM, } \\
\text { Peneliti, Dosen, } \\
\text { Aktivis Cyber. }\end{array}$ & $\begin{array}{l}\text { Keswadayaan, } \\
\text { kerjasama, } \\
\text { gotong royong, } \\
\text { jaringan sosial. }\end{array}$ & $\begin{array}{l}\text { Partisipasi } \\
\text { (voice access } \\
\text { dan kontrol) }\end{array}$ \\
\hline $\begin{array}{l}\text { Masyarakat } \\
\text { Ekonomi } \\
\text { (Private sector) }\end{array}$ & $\begin{array}{l}\text { Pelaku dan } \\
\text { organisasi } \\
\text { ekonomi }\end{array}$ & $\begin{array}{l}\text { Jasa internet dan } \\
\text { jaringan }\end{array}$ & $\begin{array}{l}\text { Akses } \\
\text { kebijakan, } \\
\text { akuntabilitas } \\
\text { sosial }\end{array}$ \\
\hline
\end{tabular}

Sumber: Eko \& Dwipayana (2003: 23).

\section{HASIL DAN PEMBAHASAN}

Peran Stakeholders di Provinsi Jawa Tengah dalam Pencegahan Penyebaran Berita Bohong (Hoax)

\section{Peran Negara}

Negara telah berperan baik dalam memberikan kepastian hukum untuk melindungi masyarakat dari kejahatan berbasis teknologi informasi. Peraturan yang telah disusun oleh pemerintah yaitu UndangUndang Nomor 11 Tahun 2008 tentang
Informasi dan Transaksi Elektronik. Pihakpihak yang terlibat dalam penyusunan peraturan ini yaitu pemerintah, swasta, masyarakat dan akademisi.

Pemerintah dalam hal ini yang menjadi stakeholders kunci, melalui Kemenkominfo Dan kemenkumham bersama-sama membahas cikal bakal tersusunnya Rancangan Undang-Undang Informasi dan Transaksi Elektronik (ITE).

Profesionalisme dari para pelaksana kebijakan terlihat dalam pelaksanaan kewenangannya dalam pemberantasan 
penyebaran berita bohong. Masing-masing pihak yaitu Polda Provinsi Jawa Tengah dan Dinas Komunikasi dan Informasi Provinsi Jawa Tengah telah melaksanakan kewenangannya dengan baik. Dari hasil penelitian menunjukkan bahwa Polda Jawa Tengah telah melakukan sosialisasi tentang apa itu berita bohong/ hoax dan sanksi yang akan diterima oleh pelaku penyebar hoax.

Informan penelitian juga sepakat bahwa pemerintah dalam upaya pencegahan berita bohong dapat dikatakan cukup preventif, yaitu dengan menyiapkan beberapa pasal yang dapat dikenakan kepada pelaku penyebar hoax.

Responsivitas pemerintah terlihat dalam sikap aparat yang tanggap terhadap laporan adanya penyebaran berita bohong dan langsung melakukan penelusuran dan pengumpulan bukti-bukti terhadap laporan tersebut. Pemerintah juga telah melakukan perubahan terhadap undang-undang ITE dan mengakomodir masukan dari masyarakat.

\section{Peran Masyarakat}

Partisipasi masyarakat dalam pencegahan penyebaran berita bohong di Jawa Tengah dari sisi keikutsertaan dalam sosialisasi masih kurang. Namun partisipasi masyarakat dalam bentuk melakukan pengaduan saat menemukan situs atau apapun yang mengandung berita bohong itu sudah cukup baik. Berikut kutipan hasil wawancara yang telah dilakukan dengan Kepala Dinas Kominfo Jawa Tengah:

"Partisipasi masyarakat kalau dalam hal ikut kegiatan itu kurang. Tapi kalau partisipasi dalam bentuk pengaduan sudah cukup baik." (wawancara Selasa, 11 Desember 2018)

Ditreskrimum Polda Jawa Tengah juga menyatakan hal yang sama,

"Masyarakat melaporkan kepada kami saat ada situs atau berita yang diketahui memuat berita bohong/ hoax." (wawancara Selasa, 11 Desember 2018)

Komunikasi dan koordinasi yang dilakukan oleh masyarakat dengan pemerintah yaitu melalui contac center dan melalui website pengaduan yang sudah disediakan.

Peran Swasta
Swasta ikut berperan aktif dalam pencegahan penyebaran berita bohong. Peran swasta ditunjukkan dengan mendukung undang-undang ITE dan memberikan masukan saat penyusunan rancangan undang-undang ITE. Swasta sendiri juga memiliki akses untuk mengetahui perkembangan dan hasil akhir dari peraturan tersebut.

Swasta turut serta berperan aktif dalam melakukan kegiatan untuk pencegahan penyebaran berita bohong sebagai bentuk akuntabilitas social. Kegiatan-kegiatan yang dilakukan oleh swasta yaitu melakukan sosialisasi di media sosial hingga mengadakan kegiatan dalam mengajak media untuk bersama-sama memerangi berita bohong.

Berikut kutipan penjelasan dari Kepala Dinas Kominfo Jawa Tengah tentang peran serta Swasta

"Mereka ikut berpartisipasi

membantu pemerintah. Swasta ikut partisipasi dengan sosialisasi di media sosial dan kegiatan lain."(wawancara Selasa, 11 Desember 2018)

\section{Kendala Pelibatan Peran Stakeholders di Provinsi Jawa Tengah dalam Pencegahan Penyebaran Berita Bohong (hoax)}

Kegiatan Sosialistik Masyarakat

Kegiatan sosialistik yang dilakukan oleh masyarakat yaitu dengan ikut serta melakukan sosialisasi bahaya penyebaran berita bohong hingga turut serta mengikuti kegiatan pemerintah dalam melawan penyebaran berita bohong. Kendala dalam kegiatan sosialistik masyarakat sendiri yaitu tidak banyak masyarakat yang ikut serta berpartisipasi dalam kegiatan ini. Ada pula masyarakat yang tidak dapat membedakan berita bohong dan tidak, terlebih lagi terdapat pula beberapa pihak yang secara sadar mengetahui berita bohong dan ikut menyebarkan.

Pemblokiran Situs Online yang Terindikasi Hoax (Pos-metro.com, nusanews.com, Islampos.com, dll)

Pemblokiran situs merupakan salah satu langkah pemerintah Provinsi Jawa Tengah dalam memerangi penyebaran berita 
bohong. Walaupun kegiatan pemblokiran tersebut tidak berdampak banyak dan hanya mengurangi situs yang mengandung berita bohong. Proses pemblokiran sendiri langsung dilakukan oleh pemerintah saat terbukti situs tersebut mengandung muatan berita bohong. Kendala dalam pemblokiran ini yaitu munculnya protes yang dilakukan oleh pemilik situs.

\section{Pemblokiran Terhadap Situs Berbau Pornografi dan SARA}

Situs berbau Pornografi dan SARA sangat rentan mengandung muatan berita bohong dan langkah pemerintah dalam pemblokiran ini hanya berdampak sedikit terhadap pengurangan situs penyebar berita bohong. Hal tersebut dikarenakan lingkungan social media sangat luas sehingga banyak akun yang mengandung pornografi dan SARA. System pemblokiran sendiri langsung dilakukan apabila pemerintah menemukan situs berbau Pornografi dan SARA. Pemerintah sendiri menjalin kerjasama dengan berbagai pihak untuk saling menginformasikan apabila menemukan situs yang berbau pornografi dan SARA.

\section{Revisi Undang-Undang}

Undang-undang tentang Informasi dan Transaksi Elektronik telah mengalami perubahan. Perubahan tersebut terdapat dalam Undang-undang Nomor 19 Tahun 2016 tentang Perubahan Undang-Undang Nomor 11 Tahun 2008. Perubahan tersebut dilakukan dengan melibatkan pihak-pihak yang terlibat dalam penyusunan rancangan undang-undang ITE. Swasta dan masyarakat turut serta dalam mereview dan memberikan masukan. Namun terdapat kendala dalam revisi undang-undang ini yaitu terlalu banyak masukan dari masyarakat yang tidak semua dapat diakomodir oleh pemerintah.

\section{KESIMPULAN}

Peran Stakeholders di Provinsi Jawa Tengah dalam Pencegahan Penyebaran Berita Bohong (Hoax)

Negara/pemerintah, swasta dan masyarakat di Jawa Tengah dalam pencegahan penyebaran berita bohong telah melakukan perannya dengan baik.
1) Pemerintah selain menyusun Undangundang Nomor 11 Tahun 2008, peran pemerintah juga melakukan perubahan Undang-undang Nomor 11 Tahun 2008 menjadi Undang-undang Nomor 19 Tahun 2016.

Penyusunan undang-undang juga telah melibatkan swasta dan masyarakat. Tindakan yang dilakukan pemerintah, swasta dan masyarakat juga sama-sama mendukung pencegahan penyebaran berita bohong. Pemerintah melakukan kerjasama dengan komunitas Masyarakat Anti Fitnah Indonesia untuk melakukan sosialisasi, membuat aplikasi anti hoax berbasis android dan melakukan kegiatan untuk mengajak masyarakat memerangi hoax.

2) Swasta melakukan kegiatan sosialisasi melalui media sosial dan juga melakukan kegiatan untuk memerangi hoax. Sebagai contoh, Telkomsel telah melakukan kegiatan mengajak media untuk bersama-sama memerangi berita bohong/ hoax.

3) Masyarakat turut serta membantu pemerintah dalam melakukan pengaduan saat menemukan situs/ akun atau segala sesuatu yang terindikasi mengandung berita bohong walaupun tingkat partisipasi masyarakat masih cukup kecil. Komunikasi antara masyarakat dan pemerintah juga terjalin dengan baik, terdapat nomor contac center, alamat email dan kotak pengaduan di wesbsite yang bisa digunakan oleh masyarakat untuk melakukan pengaduan kepada pemerintah saat menemukan sesuatu yang terindikasi mengandung berita hoax.

\section{Kendala Pelibatan Peran Stakeholders di Provinsi Jawa Tengah dalam Pencegahan Penyebaran Berita Bohong (hoax)}

1) Masih terdapat masyarakat yang tidak mengetahui Undang-Undang tentang Informasi dan Transaksi Elektronik dan juga kurangnya sosialisasi tentang literasi media kepada masyarakat.

2) Situs yang mengandung berita bohong, pornografi dan SARA sangat banyak 
dan tidak semua dapat dijangkau oleh pemerintah

3) Banyak penolakan terhadap revisi undang-undang ITE karena pemerintah memiliki akses dan berhak untuk melakukan pemblokiran terhadap situs/ akun yang menurut pemerintah terindikasi mengandung berita bohong, pornografi dan SARA.
Kismartini, dkk. (2005). Analisis kebijakan publik. Jakarta: Universitas Terbuka.

Moleong, L. J. (2004). Metodologi penelitian kualitatif. Bandung: Remaja Rosda Karya.

Soekanto, S. (2002). Teori peranan. Jakarta: Bumi Aksara.

Tangkilisan, H. N. (2003). Implementasi kebijakan publik. Yogyakarta: Lukman Offset YPAPI.

Winarno, B. (2002). Teori dan proses kebijakan publik. Yogyakarta: Media Pressindo.

\section{SARAN}

1) Melakukan sosialisasi tentang Undangundang Nomor 11 Tahun 2008 tentang Informasi dan Transaksi Elektronik kepada masyarakat melalui media cetak dan elektronik serta melakukan sosialisasi hingga tingkat kelurahan/ desa.

2) Membentuk tim gabungan antara Dinas Komunikasi dan Informasi Jawa Tengah dengan Polda Jawa Tengah yang bergerak khusus menelusuri situs/ akun yang mengandung hoax, pornografi dan SARA.

3) Melakukan pendidikan literasi media dan pelatihan pembuatan konten-konten yang baik dan bebas dari berita bohong, pornografi dan SARA untuk semua masyarakat di tingkat kelurahan/ desa dan di sekolah-sekolah serta memberikan pemahaman terhadap tindakan pemerintah yang memiliki akses dalam melakukan pemblokiran demi pencegahan penyebaran berita bohong.

\section{DAFTAR PUSTAKA}

Dwipayana, A. A. G. N. A., \& Sutoro, E. (2003). Membangun good governance di desa. Yogyakarta: IRE Press

Agustino, L. (2008). Dasar-dasar kebijakan publik. Bandung: Alfabeta

Dwiyanto, A. (2008). Mewujudkan good governance melalui pelayanan publik. Yogyakarta: Gajah Mada University Press

Hendriana. (2017). Pengaruh teknologi dan lifestyle terhadap penggunaan internet banking. Jakarta: Universitas Trilogi

Kismartini. (2004). Analisis trade-off sebagai alat analisis kebijakan publik. Jurnal Dialogue, 1(3). Undip. Semarang 
Kismartini, et al. / Analisis Stakeholders dalam Perspektif Governance .. 